\title{
Renewable Energy - a Great Energizing Potential that Eliminates Environmental Pollution
}

\author{
Enkelejda Kucaj \\ Elizabeta Susaj \\ Besjana Qaja \\ Department of Environment, Faculty of Urban Planning and Environment Management (FUPEM), University POLIS, \\ Tirana, Albania
}

\begin{abstract}
Renewable energy, efficiency energy, green industries and the development of the green economy are generally attracting attention all over the world. Albania needs investments for this type of energy, given that, in the 21st century, is still unable to fulfill the minimum needs of energy. The aim of this study was to identificate the use of solar panels in the Kombinat area by completing a questionnaire. Residents of this area who were equipped with a solar panel are asked about how they used and the benefits that they have from the solar panel, indicating that warm water is widely used in their home. Another purpose of this study was to inform the residents of this area about the economic and environmental benefits to use the solar panels. Interviewers are asked what kind of energy use to heat their homes. Arguments have been that most of them use electricity then gas. They also use woods in chimneys or stoves more over most of them said that they save $30 \%$ of the previous amount of the electricity bill. We also informed and aware the public about the negative impacts in the environment, agriculture and the economy of the country from the use of non-renewable energy. Sun light energy is absolutely free and can be utilized by all without exception and keep the environment clean during use and is also controllable by humans.
\end{abstract}

Keywords: solar panel, renewable energy, Kombinat, questionnaire, benefits.

\section{Introduction}

The purpose of this study was assessing the potentials of solar energy as an alternative source of energy for the conditions of Albania. This data (to have a general overview about solar panels) are collected at the Kombinat / Tirana area. Investments in solar photovoltaic capacities produced globally are growing rapidly, roughly sevenfold in the last decade (Sawin, 2008). Solar production has been a reliable source for power supply. Many Americans view solar energy as an environmentally friendly substitute for traditional energy sources. If solar power is not reliable, it is illogical to mandate its use and to invest billions of tax dollars in it (U.S. EIA., 2015). On a long-term view, the use of solar water heaters will significantly reduce greenhouse gas emissions, $\mathrm{CO}_{2}$ in the atmosphere as one of the main causes of global warming and will contribute to mitigating it (Ecoinvent Centre, 2007). The Intergovernmental Panel of Climate Change (IPCC) considers sulfur hexafluoride to be the most potent greenhouse gas per molecule; one ton of sulfur hexafluoride has a greenhouse effect equivalent to that of 25,000 tons of $\mathrm{CO} 2$ (Alsema et al., 1996). To identify the environmental impacts due to the largescale solar installation and operation we have reviewed scientific literature and have found approximately 32 impacts, which are divided into the sections: land use, human health and well-being, wildlife and habitats, geohydroelectric resources, climate and greenhouse gases (US-EIA 2010).

Albania, according to experts, has considerable potential to develop its renewable energy sources, particularly in solar energy. Albania is a special case, because about $10-13 \%$ of the total primary energy source (TPES), including imports, is provided by biomass, especially by firewood (ECS, 2013). By comparing the global renewable energy consumption over the last 15 years, the changes are quite noticeable. Although the global energy transition towards a cleaner power generation is not progressing at the right place, it should definitely be stimulated. 
The production of renewable energy in Europe during 2005 was $20.1 \%$, in 2010 this percentage changed to $25.7 \%$. While in 2015 energy production fall to $34.2 \%$ in different regions of Europe. These changes are good signs of replacing electricity with renewable energy (IEA, 2013).

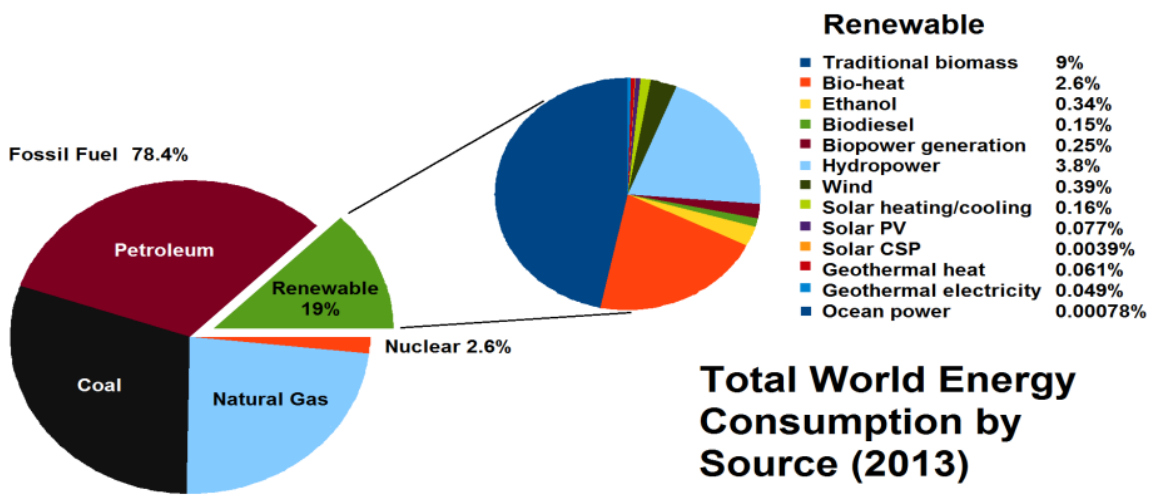

Figure 1. Total World Energy Consumption, (IEA, 2013)

Global capacity has replaced solar energy in exponential growth, reaching $227 \mathrm{GWe}$ by the end of 2015 , producing $1 \%$ of all electricity globally used. Large solar installations have been in the regions with relatively less solar resources (Europe and China), while potentials in high resource regions (Africa and the Middle East) remain untapped. China has led PV capacity installations over the last decade and continues as a leader, followed by Germany, Japan, Italy and the United States (REN21, 2016).

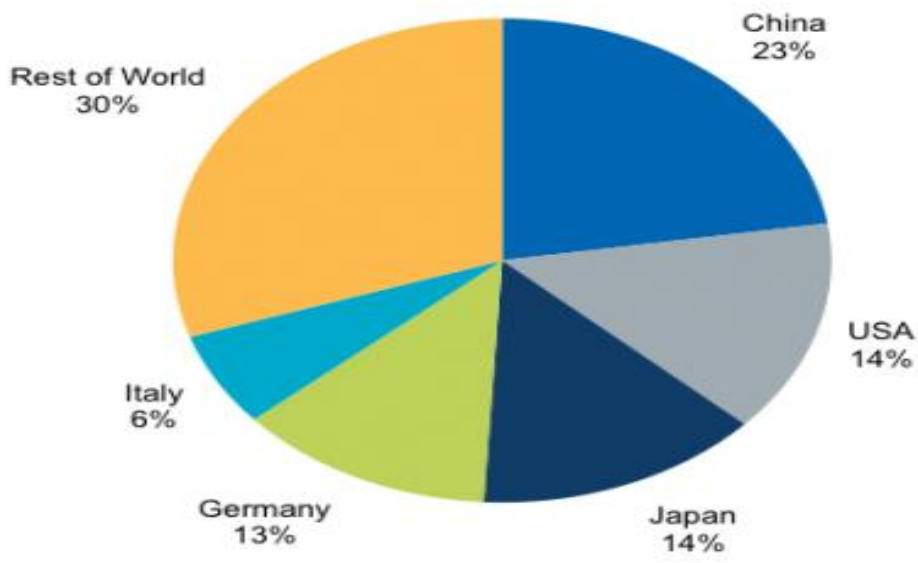

Figure 2. Cumulative Global PV installations 2016. (C.I.I., 2016).

In Tirana dominates a sub-tropical - Mediterranean climate with winter sludge and average annual temperature in July + $24^{\circ} \mathrm{C}$ and in January $+7^{\circ} \mathrm{C}$. In the year falls $1189 \mathrm{~mm}$ rain (AIDA, 2016). These temperatures are quite optimal and favor perfectly the use of solar energy by placing solar panel dwellings. 

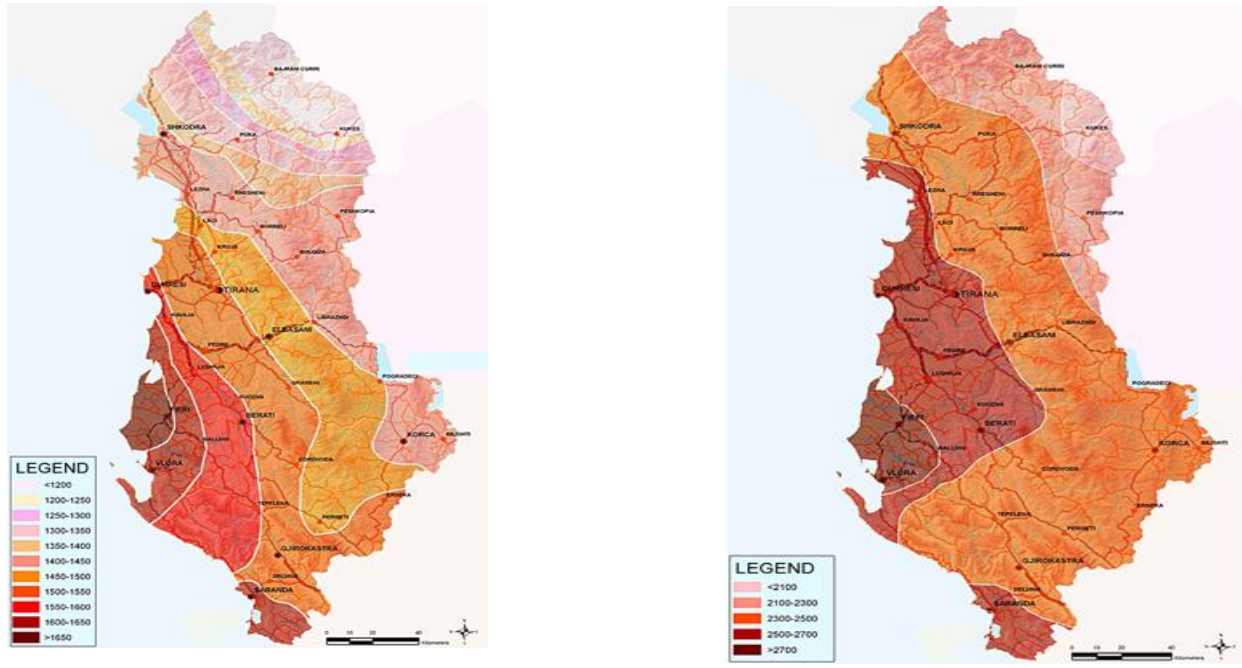

Figure 3. [1] Average Annual Radiation $\left(\mathrm{kwh} / \mathrm{m}^{2}\right)$, [2] Territorial Distribution of Sunny Hours.

\section{(A.K.B.N)}

These panels make it possible to heat water which can be used in many different forms. Also, it can be used to heat the indoor environment (through boilers). In May 2013, the Albanian parliament adopted a new Law on Renewable Energy Sources, making electricity produced from wind, solar, geothermal and biomass eligible for a feed-in tariff. It is important to note that the development of solar energy and large-scale use has a great influence on the environment, connected not only to energy, but also to water and land. For example, in Europe, 20-20-20 legislation normatives European countries to reach a share of $20 \%$ of renewable sources in total final energy consumption by 2020 (WERS, 2016). The installation of solar panels at home and business in Albania is constantly increasing.

According to INSTAT, (2014) the import of solar panels reached 379 million Albanian lek, an increase of 129\% compared to the previous year, although their use remains low in relation to the great potential they have. Various companies have expressed interest and have submitted to the Ministry, the application for construction of a photovoltaic park for the production of energy from renewable sources in different areas of Albania. One of these projects is designed in the Plug, Lushnja Municipality with a capacity of $2 \mathrm{MW}$, on an area of about 2 hectares, with an investment value of about 1 million euros (Energy.al, 2016). Albanian General Electricity SH.A. (AGE, 2016) and A.E. Distribution sh.pk, applied to build a photovoltaic park in the area of Topoje in the Municipality of Fier with an investment value of 2 million euros. In August 2016, the company "Novoselë Photovoltaic Power Plant" has requested a prior authorization from the Ministry of Energy to build a photovoltaic park aimed at producing electricity from solar radiation. The park is planned to be built in the Novosela area in Vlora. Sun and Wind Energy Corporation (2016) applied to the Ministry of Energy for the construction of two wind and sun energy production parks counting in total 45 million euros in the Pilur area in the Municipality of Himara with an investment value of about 27 million euros.

\section{Material and Methods}

The study focuses on identifying the main categories of energy users (namely, potential market), using primary solar energy sources by means of panels to be used in indoor environments but also the use of other types of energy (electrical, wood fire, gas, coal etc.).

The assessment of the study covered various categories such as public buildings, health centers, offices, cultural services, schools, commercial buildings such as small supermarkets, and tourist facilities such as hotels, restaurants, agricultural facilities (greenhouses, storage) as well as other types of agro-industrial companies. This assessment was made by completing a questionnaire in the Kombinat area (Tirana) during the period May-April 2017. The questionnaire was in a 
draft form and interviews on various questions to get more information on how to use other types of energy (electricity, firewood, gas, coal etc), use of solar panels, the benefits they have and so on.

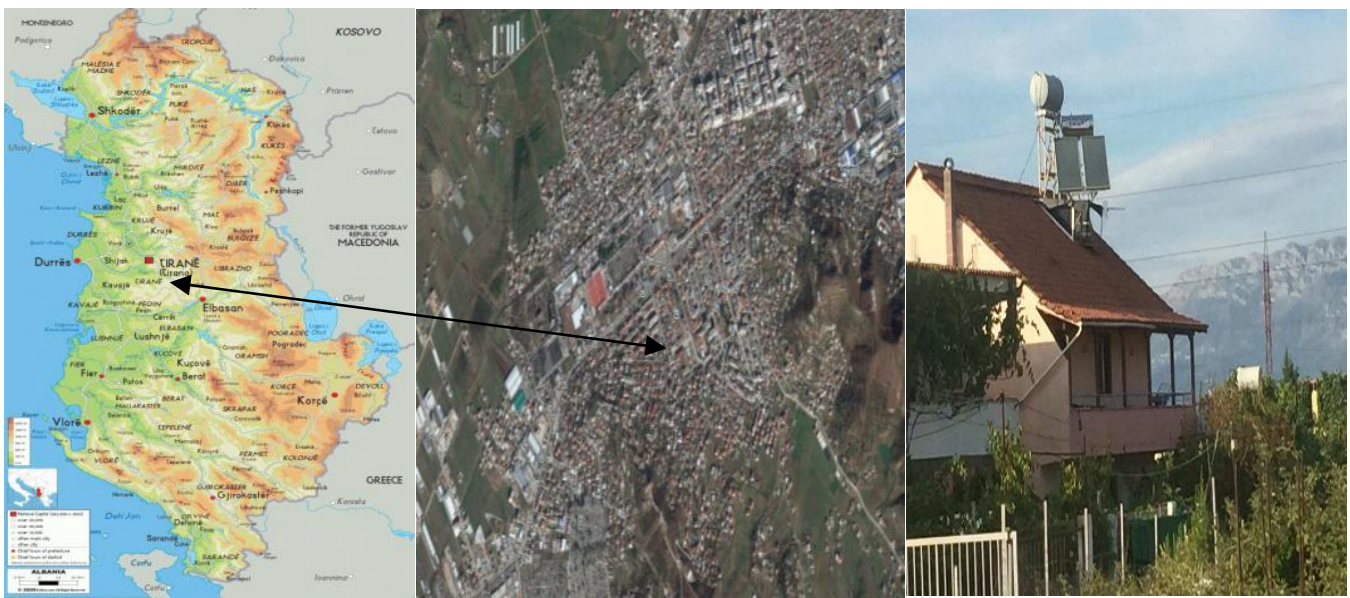

Albanian map

(2) Kombinati map

Figure 4. Area taken in study

\section{Results and Discussion}

Climate change has resulted in irregular rainfall for Albania, longer and drier summers and less snowfall in the mountains (Bruci, 2008). The use of energy has increased as a result of the numerious buildings and the number of electrical appliances which are expected to increase too.

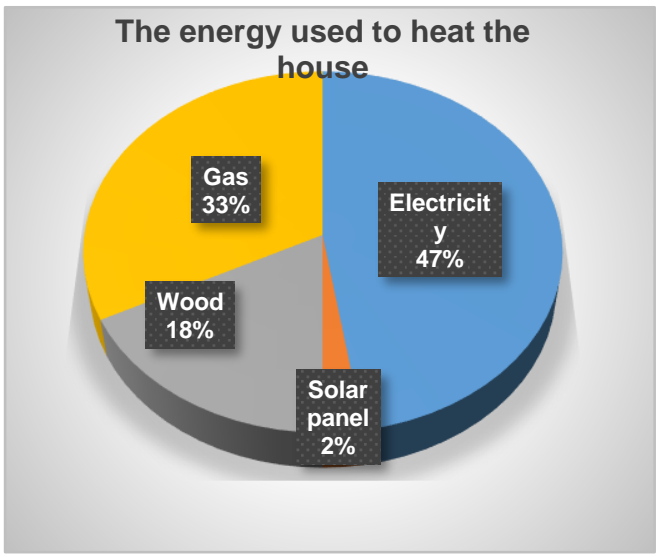

b)

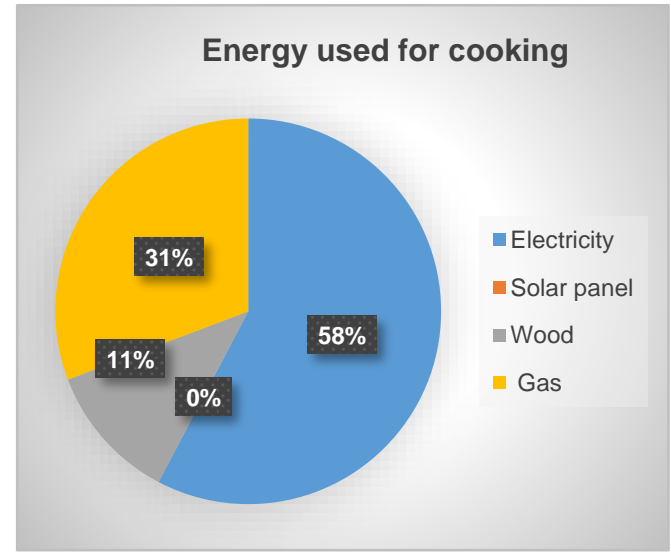

Figure 5. Types of energies used a) to heat the house b) for cooking

The Figure 5 a) Interviewers were asked what type of energy they use to heat water in their homes. From the interviews feedback, hotel businesses have declaired they would like to use solar panels for central heating, but this was not realized due to the high cost and the management developed so far. Also there are families who use more than two sources causing pollution to the environment. At Figure $5 \mathrm{~b}$ ) is showing that residents use more electricity and gas than wood for cooking. In this area we have a shortage of using solar panels in the form of electricity. 
In Figure 6, 33\% households use electricity and gas, and $60 \%$ of them use solar panels to heat the water which it is used for bathing. In fact we are focused on those families who are equipped with the solar panel therefore the number of users is significant. On the other side there are families who use this source in alternate maner.

\section{The energy used to heat the water}

30

20

10

0
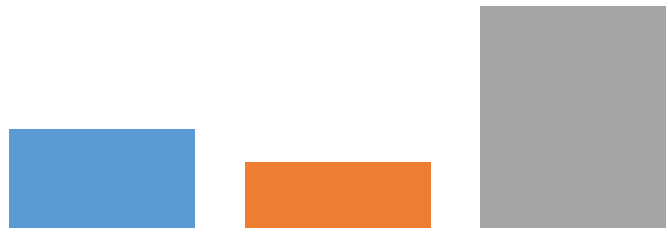

Electricity $\quad$ Gas $\quad$ Solar Panel

Figure 6. Types of energies used to heat the water

Most of them said that they saved about $30 \%$ of the previous of electricity bill. The average on the basis of the calculations was 7-8 thousand Albanian lek per month. We can emphasize that higher value savings have been made by restaurants and hotels that have a greater use of water quantity.

\section{Conclusion}

Albania needs to make voluntary commitments because not only developed countries that have historic responsibility for global warming and climate change, but also the developing countries need to be active. Energy obtained from solar panels keeps the environment clean and contributes to the elimination of carbon dioxide, nitrogen oxides, sulfur dioxide, and other pollutants that can be caused by the debris generated during the local service.

Also, it is economically affordable and manageable by people. Albanian has a perfect geographic position and climate conditions which favors the installation of solar panels in every home, institutions and businesses. According to the questionnaire, the people were pronounced that they have saved almost $30 \%$ of the previous total electricity bill.

\section{References}

[1] AIDA (Albanian Investmen Divelopmen Agency). (2016). Informacion i pergjithshem mbi Klimen ne Shqiperi. http://aida.gov.al/faqe/informacion-i-pergjithshem-mbi-klimen-ne-shqiperi

[2] A.K.B.N. AGJENCIA KOMBËTARE E BURIMEVE NATYRORE. http://www.akbn.gov.al/images/pdf/energji-terinovueshme/Energjia_Diellore.pdf

[3] Alsema, E., Baumann, A., Hill, R., Patterson, M. (1996). "Health, Safety and Environmental Issues in Thin Film Manufacturing," Report, Department of Science, Technology, and Society, Utrecht University, The Netherlands, 1996.

[4] Bruci, E. (2008). Climate Variability and Trends in Albania. Institute of Energy, Water and Environment, Tirana Polytechnic University, Tirana, Albania.

[5] C.I.I. (2016). IHS - The Source for Critical Information and Insight (2016). https://technology.ihs.com/

[6] IEA 2013., International Energy Agency 2013. IEA Annual Report.

[7] https://www.iea.org/publications/freepublications/publication/2013_AnnualReport.pdf

[8] Ecoinvent Centre (2007). Ecoinvent 2000 version 1.3. Swiss Centre for Life Cycle Inventories. Dübendorf

[9] Energy.al, 2016. http://energjia.al/?s=panelet+dellore 
[10] Energy Charter Secretariat (ECS). (2013). In-Depth Review of the Energy Efficiency Policy of ALBANIA. Available at: www.encharter.org/fileadmin/user_upload/Publications/Albania_EE_2013_ENG.pdf

[11] INSTAT (2014). http://agroweb.org/?id=10\&l=365\&ln=sq

[12] REN21 (2016). Renewables 2016, Global Status Report. http://www.ren21.net/wpcontent/uploads/2016/06/GSR_2016_Full_Report.pdf

[13] Sawin, J. (2008). "Another Sunny Year for Solar Power," Vital Signs Report, World Watch Institute, May 2008.

[14] US-EIA. Electric power monthly. Washington, DC: U.S. Energy Information Agency; 2010. September.

[15] U.S. Energy Information Administration. (2015, March 12). Direct federal financial interventions and subsidies in energy in fiscal year 2013. Retrieved from http://www.eia.gov/analysis/requests/subsidy/ 2 U.S.

[16] WEC (World Energy Council). (2016). World Energy Resources Solar | 2016. https://www.worldenergy.org/wpcontent/uploads/2016/10/World-Energy-Resources-Full-report-2016.10.03.pdf 